\title{
The case of the midwife toad revisited
}

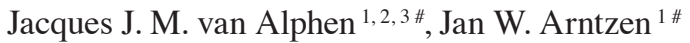 \\ ${ }^{1}$ Naturalis Biodiversity Center, P.O. Box 9517, 2300 RA Leiden, the Netherlands \\ ${ }^{2}$ Institute for Biodiversity and Ecosystem Dynamics, University of Amsterdam, P.O. Box 94248, 1090 GE Amsterdam, \\ the Netherlands \\ ${ }^{3}$ E-mail: jacques.vanalphen@gmail.com \\ " both authors contributed equally to this work
}

Keywords: Acquired characteristics, Alytes, epigenetics, fraud, Lamarckian evolution, Mendelian ratio, parent of origin effect, Paul Kammerer, scientific misconduct

\begin{abstract}
In a recent paper it was suggested that results published by Kammerer (1911) on the midwife toad could be explained by epigenetics (Vargas et al., 2016). We show that data thought to be fitting are based on untested assumptions about the underlying genetic mechanisms. We cite recent studies on the genetics of life history traits, in particular egg-size and number, to show that these assumptions are not realistic. We review aspects of Kammerer's experimental results on the midwife toad for which there are no plausible mechanisms, i.e. toads switching from landbreeding to water-breeding in response to an increase in temperature, eggs becoming resistant to moulds within a few generations, the gradual development of nuptial pads, heterochronous changes in the development of water-born larvae, and conclude that Kammerer cannot have obtained the results he claims. We argue that natural selection would not have favoured a change in reproductive mode and the loss of parental care and that an epigenetic master switch, affecting many different traits simultaneously, would have either eroded during more than 15 million years of land-breeding and/or would have disappeared by natural selection against it. Finally, we show that Kammerer's data are remarkably close to the invoked Mendelian ratio and too good to be genuine. We conclude that Kammerer's data are fictitious and that Vargas et al. (2016) have used non-existing data in search of support for a role of epigenetics in neoLamarckian evolution.
\end{abstract}

\section{Contents}

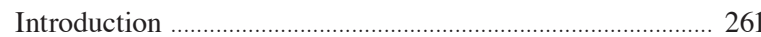

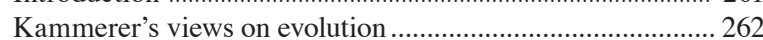

Kammerer's Alytes experiments: design and results ............ 263

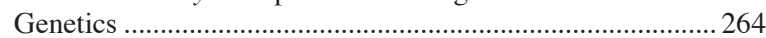

Natural selection................................................................. 265

Unexplainable aspects in Kammerer's experiments............... 265

Resistance of the eggs to aquatic moulds ......................... 265

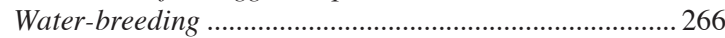

Egg size, number, and development ................................... 266

Mating behaviour and nuptial pads ................................. 266

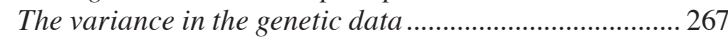

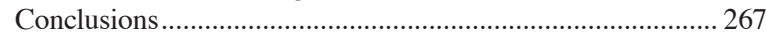

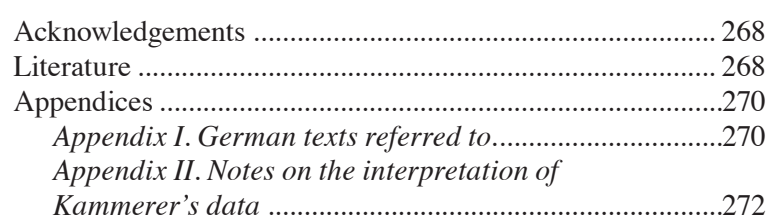

\section{Introduction}

It is about a century ago that the Viennese biologist Paul Kammerer published his works on lizards, sea squirts and a variety of amphibian species. The results of his experiments invariably seemed to show that the animals he studied were plastic in their reproductive behaviour, colour or morphology when challenged with environments other than the natural one. Moreover, his data seemed to show that, in at least two species - the fire salamander and the midwife toad - these changes were inherited by next generations and thus evidence for Lamarckian evolution. Although his work was criticized by some of his contemporary colleagues, it lasted until long after the First World War before Paul Kammerer was publicly accused of scientific misconduct. The American herpetologist G. K. Noble inspected the last remaining specimen of a male midwife toad that was supposed to show nuptial pads, and found spots of injected Indian ink instead. This observation was published in Nature (Noble, 1926) and irremediably damaged Kammerer's scientific credibility and the scientific community further ignored his work until 1971, when Arthur Koestler's book "The Case of the Midwife Toad" renewed interest in Kammerer and his research. Koestler suggested that the midwife toad under scrutiny may have been tampered with by somebody else and depicted Kammerer as the victim of National Socialists sympathisers at the university of Vienna. He did not raise much doubt about the other research being 
genuine and discounted the possibility that Kammerer would have been a fraud himself. Recently, new publications have appeared, building on Koestler's (1971) speculations, suggesting that Kammerer was not only the victim of an anti-Semitic conspiracy (Taschwer, 2016), but also a scientist ahead of his time, reporting the first evidence for epigenetics (Vargas, 2009; Vargas et al., 2016).

Evidence for the role of epigenetics in evolution is scarce or absent. If Vargas (2009) and Vargas et al. (2016) would have been right, Kammerer would also have been the first person to provide evidence for the role of epigenetics in evolution. Although plants have diverse pathways overseeing the faithful passage of the methylome to daughter cells, there is little evidence that the environment induces changes in DNA methylation in plant genomes (Wibowo et al., 2016; Akst, 2017). In animals it is even less likely that environmentally induced epigenetic changes are passed on to the next generation, because the CG marks are wiped out in two rounds of reprogramming in the gamete and the early embryo. It thus remains controversial whether germline DNA methylation in animals remains stably heritable (Nagase and Gosh, 2008).

We reviewed Kammerer's research on fire salamanders and blind cave salamanders and concluded that it was Kammerer himself that committed fraud in these studies (van Alphen \& Arntzen, 2016). As the claims for Kammerer being the first to find evidence for epigenetics are based on his work on midwife toads, we decided to review Kammerer's experiments on this species as well, and evaluate if epigenetics could explain the results. The reason behind our effort is that Vargas (2009) and Vargas et al. (2016) only deal with a simplified version of the results of Kammerer's experiments and fail to mention important details that would also have to be explained by epigenetics, but are hard to reconcile with present day knowledge.

\section{Kammerer's views on evolution}

Kammerer believed that evolution by the inheritance of acquired characters was far superior a mechanism to evolution by natural selection. In his book "The Inheritance of Acquired Characteristics" (Kammerer, 1924) there is even a chapter titled "The Impotency of Selection" in which he argues that selection can only slightly modify acquired characters. For Kammerer an acquired character was the same as a mutation, however, with the important difference that the new char- acter was acquired by the soma, and had to be imprinted on the germ line to become heritable. He was convinced that all amphibians are phenotypically plastic in reproductive biology. For example, citing Jourdain on Hylodes (now Eleutherodactylus martinicensis (Tschudi, 1838), a Caribbean frog that has direct development and hatches from eggs as froglets, he writes "I am convinced that, with the help of the appropriate measures, one could get any amphibian to show the remarkable reproductive behaviour of Hylodes or at least to approach this behaviour" (Kammerer, 1906:66) (our translation, as elsewhere where the original is in German; the original texts are reproduced in Appendix I). When he did not succeed to induce direct development in the midwife toad (genus Alytes) he says: "Today, however, I do no longer have any doubt, that it is within reach of the possibilities, to force Alytes to develop without metamorphosis and independently of water" (Kammerer, 1909: 523). However, even when Kammerer's thoughts would have been correct, more important than showing that the reproductive behaviour of amphibians could be modified was to show that such changes could be passed on to next generations. August Weismann (1887) published experiments in which he removed the tails of mice during five generations and showed that this did not result in mice born without tails. From then on, Lamarckists insisted that only adaptive traits could be acquired and a proof of Lamarckian evolution is thus to include evidence that the traits under study are adaptive.

Kammerer was aware of Weismann's (1893) germ plasm theory, but believed that somatic adaptations, by some unknown mechanism could pass the "Weismann barrier", would reach the germ-line cells and become heritable. Evidence for such a process would come from data showing that: (1) the reproductive performance of animals placed in a new environment would improve with each reproductive cycle and, more importantly (2) $F_{1}$ offspring kept in the new environment would perform better than the parents, and later generations would perform better than the $\mathrm{F}_{1}$. Thus, when he set out to show that the land-breeding midwife toads can acquire adaptations to breed in water, he had to show that they develop all the adaptive features that water-breeding toads and frogs have, and that they would develop these adaptations gradually.

Kammerer (1909) predicted that adaptations to a new environment would slowly disappear when the animals were returned to their original environment. This seems perfectly logic: when animals adapt to a new environment by acquiring new characters, they 
should as easily adapt again to their former environment. However, this re-adaptation posed a problem for a researcher who wanted to show that an acquired character had become a heritable trait. When the next generation is returned to the original habitat of the parents, it loses the new character, but when the next generation is kept in the new environment, it might show the new character not because it had inherited that character from its parents, but because it has acquired the character itself. Kammerer had two potential solutions for this problem. First, if he could show that the $F_{1}$ and subsequent generations would be better adapted than the parents, then this would show that an effect on the parents had been transferred to following generations. The second solution was to cross an animal with the acquired character to one from the wild population and study the frequency of the character in the $F_{1}$ and $\mathrm{F}_{2}$. If this frequency fitted Mendel's laws, then, in his view, the character had become heritable. This motivated Kammerer (1911) to perform crossing experiments between wild-type midwife toads and those from his raised-temperature experiments.

Kammerer (1919) claims that there are also newly acquired characters that do not disappear after the animals are returned to the original environment. He does not offer an explanation as why some characters would disappear whereas others would become genetically fixed, except for the idea that atavistic characters would sooner become fixed than real novelties. Citing Weismann, Kammerer 1919:348 writes "We deal here with a set-back of the reproductive mode of ancestors from a long time ago, which had been given up since hundreds of generations, but which had not totally disappeared from the germ plasm and becomes reactivated when the proper stimuli are applied.".

\section{Kammerer's Alytes experiments: design and results}

Four publications report on Kammerer's experimental work with Alytes (Kammerer 1906, 1909, 1911 and 1919). The data that inspired Vargas (2009) and Vargas et al. (2016) to suggest an epigenetic explanation for the experiments are described in the 1909 and 1911 publications, that we here summarize. Note that the terms 'eggs' and 'embryos' (fertilized eggs) are here used interchangeably.

The 1909 publication is based on experiments in terrariums with three experimental groups, each initiated with 15 males and 15 females. One group was kept in an unheated room, one group was kept in a room at temperatures of $25-30{ }^{\circ} \mathrm{C}$ and one group was placed in a room kept at $35-40{ }^{\circ} \mathrm{C}$. The latter group was soon abandoned, as the high temperature turned out to be lethal for the experimental animals. No bookkeeping was done on the identity of the parents of the clutches. No data are provided on mortality and the number of offspring successfully reared. A fourth group of animals was kept in an outdoors terrarium and served as a source of new experimental animals. Experiments were continued for at least four generations. No data were provided on the numbers of animals in the experimental groups of the new generations. Kammerer claimed that the experiments in which he exposed midwife toads to temperatures between 25 and $30{ }^{\circ} \mathrm{C}$ resulted in the following changes in comparison to free living animals or animals kept in an unheated room:

(1) Behavioural changes. Males exposed to temperatures between 25 and $30^{\circ} \mathrm{C}$ gave up parental care of the embryos, the sexes paired in the water instead of on land (Kammerer, 1909), in subsequent reproductive cycles even without the stimulus provided by a higher temperature (Kammerer, 1919).

(2) Changes in egg size and egg number. Females exposed to temperatures between 25 and $30{ }^{\circ} \mathrm{C}$ laid larger clutches of smaller eggs.

(3) Changes in resistance of the eggs. Initially, the majority of eggs laid in water succumbed due to infection with Oomyceta such as Saprolegnia, but eggs seemed to become resistant against these moulds, already in later reproductive cycles by the same parents, and more so in subsequent generations.

(4) Changes in development. Water-born larvae emerge before the horny external beaks develop, with external gills and a distinct yolk-sac. These larvae develop into adults in several months, whereas larvae emerging from land-eggs take over a year to reach adulthood.

(5) Morphological changes. Males of midwife toads raised at temperatures between 25 and $30^{\circ} \mathrm{C}$ gradually developed nuptial pads, i.e. in two to four generations. Eggs produced at these temperatures developed thicker gelatinous coats and had smaller yolk masses.

In 1911 Kammerer reports the data of his crossing experiments between water- and land-breeding midwife toads. He claims that when the father is landbreeding and the mother water-breeding, all animals of the $\mathrm{F}_{1}$-offspring are land-breeding and that three quarters of the $\mathrm{F}_{2}$-offspring is land-breeding and one quarter is water-breeding. Likewise, when the father is water-breeding, all animals in the $\mathrm{F}_{1}$ are water-breeding, 
three quarters of the $\mathrm{F}_{2}$-offspring is water-breeding and one-quarter is land-breeding. Importantly, these results seem to be in agreement with a "parent of origin effect", in this case operating through the father and appear to be the main reason for Vargas et al. (2016) to suggest that epigenetics could explain Kammerer's (1911) results. Kammerer (1911) treats "land-breeding" and "water-breeding" as alleles of a single gene. Vargas et al. (2016) do not question this and do not discuss how a different genetic architecture might affect the interpretation of Kammerer's data.

In nature, male midwife toads have been observed to call to attract females at temperatures up to $22{ }^{\circ} \mathrm{C}$ (Llusia et al., 2013). This begs the question how a moderate increase in temperature could provoke all these simultaneous changes. Vargas et al. (2016) suggest that the mechanism for the reactivation consists of epigenetic switches that act in concert on the genes involved. All Alytes species breed on land and have male parental care. They diverged from the other, water-breeding discoglossid frogs such as in the genera Bombina and Discoglossus ca. 140 million years ago. The reproductive mode of terrestrial breeding with paternal care predates the most recent common ancestor of the five extant Alytes-species, which amounts to ca. $15 \mathrm{Ma}$ (Arntzen \& García-París, 1995; Martínez-Solano et al., 2004). The hypothesis of Vargas et al. (2016) implies that the genetic architecture underlying all the changes listed above has been conserved since the split between Alytes and the other discoglossid frogs. Characters that are either not expressed or not adaptive are subject to genetic degeneration, as, for instance, the loss of scleral ossification and eyesight in cave fish (Yoshizawa et al., 2012; Meng et al., 2013; O’Quinn et al., 2015) Thus, such a scenario is only plausible when switching from landbreeding to water-breeding at temperatures above $25^{\circ} \mathrm{C}$ (and the reverse at temperatures below $25^{\circ} \mathrm{C}$ ) would be adaptive. Vargas et al. (2016) do not provide any evidence for this. Moreover, they accept Kammerer's (1911) data as genuine, without any further analysis.

In the following we will: (1) provide evidence in favour of a multigenic architecture at the basis of all the changes reported by Kammerer - if these were to exist - and show how this affects the interpretation of Kammerer's (1911) genetic data, (2) address the question if a mechanism as suggested by Vargas et al. (2016) would have been favoured and maintained by natural selection, (3) discuss the possible role of selection in Kammerer's experiments, and (4) look critically at some of Kammerer's $(1911,1913)$ numerical data and address the question if they are genuine.

\section{Genetics}

The crossing experiments reported in Kammerer (1911, 1924) are between water-breeding and land-breeding midwife toads. Vargas et al. (2016) have based their explanation on a single gene interpretation and conclude on a "parent of origin effect". They say this "is found in epigenetic mechanisms that selectively inactivate a gene in only one of the sexes". However, "land-breeding" and "water-breeding" are, in Kammerer's description, adaptations in a whole suite of characters, including: (1) the behaviour to choose a mating site, (2) absence or presence of male parental care, (3) absence or presence of nuptial pads, (4) resistance of eggs to Oomyceta, (5) egg size, (6) egg morphology, (7) female fecundity, (8) the developmental stage at which larvae hatch from the eggs, and (9) age at first reproduction. It is hard to believe that all these traits are the expression of a single gene. Similarly, there is no reason to assume that the multiple genes involved in these characters would be tightly linked as to form a "supergene". Kammerer (1911) used egg size and fecundity to recognize water- from land-breeding females, and presence or absence of male parental care to recognize water- from land-breeding males. These are very different traits, unlikely to be coded for by the same gene. By using egg-size and fecundity to classify the females as landor water-breeding, Kammerer tacitly assumed that these traits were completely linked to the operational breeding mode, like the presence or absence of male parental care. However, if we assume the most simple genetic architecture with just two genes segregating independently, with two alleles each, one gene for male parental care and one gene for egg size, then, any experimenter in charge would classify no more than $25 \%$ of the females correctly as land-breeding or water breeding.

Heritability and QTL studies in animal groups as different as birds (Bentz et al., 2016; Yi et al., 2015; Santure et al., 2013), fish (Huppop \& Wilkens, 1991), bristleworms (Miles et al., 2007) and insects (Bauerfeind \& Fischer, 2007) have shown that egg size and female fecundity are complex quantitative traits influenced by many genes positioned on different chromosomes, as is the case for development and other life history traits in the Amphibia (Voss et al., 2012; Hangartner et al., 2012). Any more complicated genetic architecture would render the classifications even less accurate as the relation between egg size and breeding mode weakens further when more genes are involved. Therefore, the numbers provided 
by Kammerer (1911) do not genuinely represent numbers of land- and water-breeding animals and, thus, it cannot be concluded that one quarter of the $\mathrm{F}_{2}$-offspring belonged to one and three quarters to the other breeding model. As egg-size and fecundity are determined by a number of quantitative trait loci on different chromosomes, egg size and number should show continuous variation. This would have created an additional problem for Kammerer (1911) in classifying animals of the $\mathrm{F}_{2}$ generation as water- or land-breeding. However, Kammerer's (1911) data on egg-size and number are strongly bimodal and such is hard to explain given the genetic architecture of the traits. Hence, the data provided by Kammerer do not provide support for a role of "parent of origin" effect and epigenetics in explaining Kammerer's enigmatic claims.

\section{Natural selection}

The simultaneous changes in many characters, induced by the temperature treatment in Kammerer's experiments, involve a large number of genes. A mechanism that would reactivate or silence these genes when temperatures rise above $25^{\circ} \mathrm{C}$ would disintegrate by random mutations or selection against it if it was not used during millions of years. If midwife toads would have used the switch and reverted to water breeding without parental care when temperatures exceeded $25^{\circ} \mathrm{C}$, most of the eggs would have perished to infections by Oomyceta (see next chapter) and young larvae would have suffered from high predation rates. The adaptive value of male parental care on land in Alytes (Figure 1) is that it reduces egg mortality and predation risk. The in-

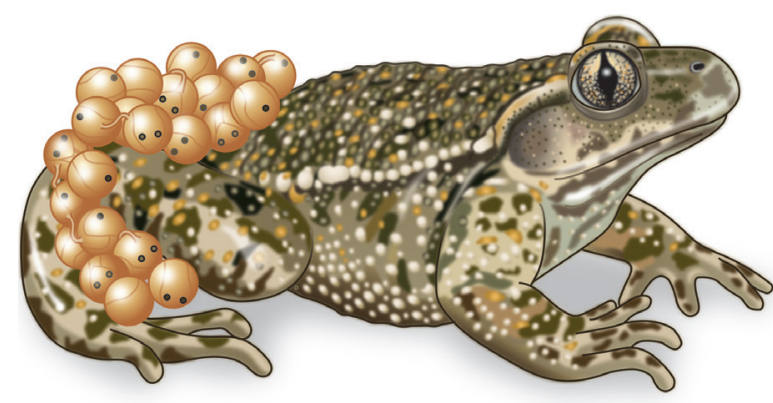

Figure 1. Male midwife toad (Alytes obstetricans) carrying a batch of developing embryos. The drawing is by Bas Blankevoort @ Naturalis Biodiversity Center. Excellent footage on the breeding behaviour of the midwife toad can be seen at https://vimeo.com/86142455. crease in fecundity of water-breeding midwife toads reported by Kammerer (1909) would not have been enough to compensate for the increased mortality and natural selection would have acted against the preservation of the switching mechanism.

Midwife toads have an extended breeding season, lasting from spring throughout summer. A moderate increase in temperature to $25-30{ }^{\circ} \mathrm{C}$, as in Kammerer's experiments, is within the variation of an Iberian summer. A warm spell would, in Kammerer's view, have caused the midwife toads to breed in water, but such warm spells are too short to last more than one breeding attempt. As adaptation to higher temperatures, according to Kammerer, occurs only gradually and after a number of generations, the switch to water would have reduced their reproductive success to almost zero, making that natural selection would have favoured animals that continued to breed on land. The genetic architecture proposed by Vargas et al. (2016), involving epigenetic switches on many different loci, would thus also have been selected against.

\section{Unexplainable aspects in Kammerer's experiments}

\section{Resistance of the eggs to aquatic moulds}

Many researchers have tried to breed Alytes larvae from eggs placed in water, but they failed as all eggs died from Oomycete infections (De L'Isle du Dreneuf, 1873; Fischer-Sigwart, 1885; Boulenger, 1912; Nijs, 1985). Midwife toads in nature breed on land and are normally not exposed to the water dwelling moulds. Moreover, soon after an egg is laid, the exterior gelatinous layer toughens and forms a cover that protects the egg from fungi. So, under natural conditions, they are not exposed to the fungi that attack amphibian eggs in water. Alytes has no recent co-evolutionary history with aquatic fungi such as Saprolegnia and, as a consequence, no resistance against them. Kammerer admits that mortality of Alytes-eggs placed in water is high: "Ultimately, the eggs stay behind in the water, where, indeed, most of them perish (in the first breeding attempt of that kind), but a few of them then still continue their development." (Kammerer, 1919:326). He claims that mortality decreases with subsequent breeding attempts of the same animals: "Later, the results improve considerably; in later generations of animals with completed instinct variation, the mortality of water eggs is hardly higher than that of other frog eggs that are normally laid in water." (Kammerer, 
1919:356). The only possible mechanism for such a rapid decrease in egg mortality would be that eggs became resistant to Oomycetes. There is substantial evidence that resistance of amphibian eggs to Oomycetes has a genetic basis and that maternal effects do not represent a major contribution to variation in infection of eggs and embryos (Sagvik et al., 2008ab; Ault et al., 2012; Urban et al., 2015). We fail to recognize any plausible mechanism for how subsequent clutches of the same mother could become increasingly resistant. Kammerer's (1909) experiments were started with a moderate number of adults, the $\mathrm{F}_{1}$ generation suffered massive mortality, resulting in a genetic bottleneck. Thus, selection in his experiment cannot have resulted in massive resistance against a community of Oomycetes species within one or two generations. It is even more difficult to understand how the epigenetic activation or the inactivation of one or more genes could confer resistance of eggs against pathogens to which they have not been exposed before. Hence, it is simply hard to believe that Kammerer succeeded in breeding the large numbers of water-breeding midwife toads he mentions in 1906 and in his crossing experiments (Kammerer, 1911).

\section{Water-breeding}

It is unclear why a rise in temperature would have induced the midwife toads in Kammerer's experiment to move to the water basin and spend most of their time in the water. Kammerer (1909:462) says “... it is the unusually high temperature that forces them to spend much more time in the water..." and he explains this by saying that "... animals that have to endure disagreeable temperatures go into the water to cool themselves ...". This cannot be true for his experiments, as the water in the basin must have had the same elevated temperature as the room and the terrarium. Later, Kammerer (1919:325) adds a different explanation: "Alytes, as most nocturnal amphibians, likes it cool, and looks for a cool place and shelter against desiccation of the skin in the water as soon as the air becomes too warm." (italics are ours). It is unlikely that the elevated temperature would have caused a low air humidity, as there was a water basin in the terrarium and there was only little ventilation. Moreover, breeders report difficulties in breeding Alytes obstetricans (Laurenti, 1768) indoors even under circumstances mimicking the natural world. The Iberian congeneric A. cisternasii Boscá, 1879 and A. muletensis (Sanchiz $\&$ Adrover, 1977) appear easier in this respect but were not available to Kammerer (Tonge and Bloxam, 1989; Bloxam and Tonge, 1995; Michaels et al., 2016).

\section{Egg size, number, and development}

Water-breeding frogs and toads lay smaller eggs and in larger numbers than the land-breeding midwife toads. Based on this observation Kammerer expected midwife toads to develop the same adaptations, when forced to breed in water. Egg size and female fecundity are heritable traits, hence selection on egg size in experiments is possible. However, in Kammerer's experiments there was no direct selection on egg size and number. It is hard to see how an increase in temperature could have selected for smaller eggs and higher fecundity.

Kammerer describes morphological changes of the eggs: they develop more voluminous gelatinous coats and yolk decreases with subsequent breeding cycles and generations. Embryonic development in water is heterochronous in comparison to eggs developing on land. This change involves a suite of adaptations, of which it is unlikely that they can be brought to expression by a mild increase in temperature.

\section{Mating behaviour and nuptial pads}

It is hard to understand how the experiment described in the Kammerer (1919) paper could have resulted in $\mathrm{F}_{1}$ water-breeding offspring without parental care, irrespective of the temperature regime applied. Selection in one generation cannot have resulted in the disappearance of the normal breeding behaviour, and the animals continuously kept at lower temperatures after exposure to the experimental temperatures might be expected to have resumed the original land-breeding behaviour.

According to Kammerer, water-breeding males developed nuptial pads, but these did not appear until the third generation. At that stage of Lamarckian evolution, the pads were scarcely visible and only they became fully expressed in the fifth generation. An epigenetic explanation of the appearance of the nuptial pads must also explain why the expression of this character increases gradually over the generations. If Kammerer really produced male midwife toads with nuptial pads in his experiments, the most likely explanation is that he had used a wild-caught male with nuptial pads (as are rarely found in nature, see Kändler, 1924) and, with this very male, raised offspring also in possession of nuptial pads. 


\section{The variance in the genetic data}

Kammerer explicitly states that he predicts Mendelian ratios to apply for the offspring in his crossing experiments (Kammerer, 1911). Actually, the numbers of water- and land-breeding $\mathrm{F}_{2}$-offspring provided by Kammerer (1911:101-104) are remarkably close to the expected 3 to 1 Mendelian ratio. In the four Alytes-experiments, with sample sizes in the 20-28 range, the differences between the observed values and those suggested by the Mendelian ratio are $-0.5,0,0$ and 0.5 (see Appendices I and II). However, for unbiased sampling at sample sizes of $\geq 20$ the expected deviates (lobservation minus the meanl) have an average well in excess of unity. This raised our suspicion as to the nature of Kammerer's data. We hence investigated other results of which Kammerer said they were in support of the 3 to 1 Mendelian ratio and found 11 observations on crosses of different phenotypes of the fire salamander, namely the spotted 'typical form' and the striped 'taeniata' form (Kammerer, 1913:131), that are currently known as the subspecies Salamandra salamandra salamandra Linnaeus, 1758 and Salamandra salamandra terrestris Lacépède, 1788. The argument is reminiscent of the Mendel-Fisher controversy and for all possible intricacies and subtleties involved in the conscious or unconscious mechanisms operating in data gathering that could explain certain biases we refer to Franklin et al. (2008) and references therein. As for Kammerer's results, we found our concern vindicated (Figure 2). The chance for finding results as close as observed to the Mendelian ratio are $0.5^{10}$, i.e. $\mathrm{P}<0.001$ for the fire salamander and $0.5^{14}$, i.e. $\mathrm{P}<0.0001$ for the two data sets combined. We propose that there can be no reasonable doubt that Kammerer's data are too good to be genuine.

\section{Conclusions}

The results that Kammerer claims to have obtained by forcing midwife toads to breed in water are difficult to explain with current biological knowledge. Selection in his experiments by the raised temperature could not have produced the simultaneous changes in so many traits. The numbers of animals used and the number of generations his experiments lasted are not sufficient to obtain such results. Invoking epigenetics to explain the results requires that a large number of genes, distributed over different chromosomes would all have to be silenced or switched-on simultaneously. Even if one

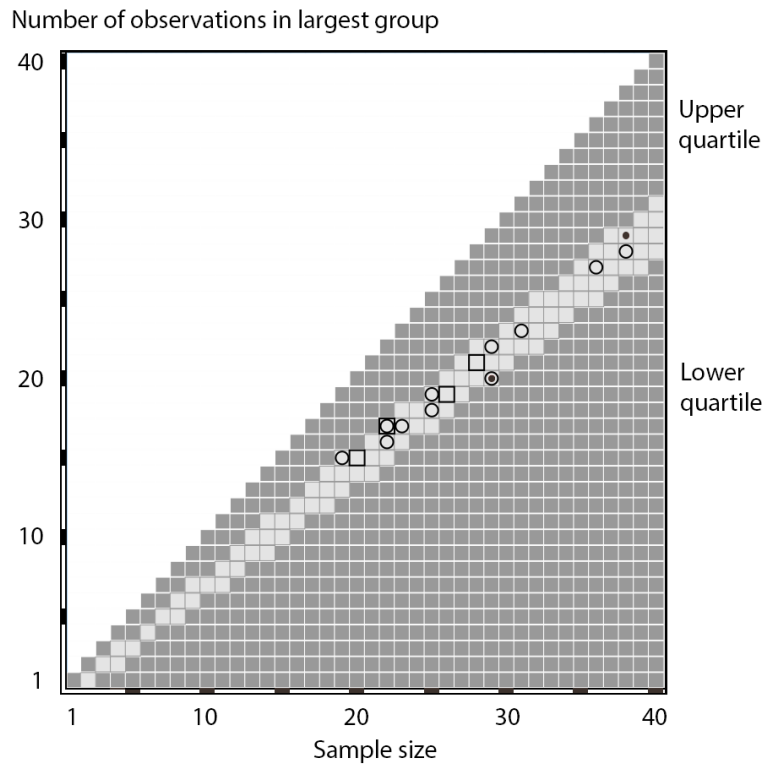

Figure 2. Cumulative probabilities of the binomial distribution for the 3 to 1 Mendelian ratio at sample sizes $\leq 40$. Published data are shown by open square symbols $(\mathrm{N}=4$, midwife toad; Kammerer, 1911:101-104) and by open round symbols ( $\mathrm{N}=11$, fire salamander; Kammerer, 1913:131). Unbiased data would be equally distributed over the four quartiles, whereas the given data all fall in the second and third quartiles (light shading) and none in the first or fourth quartile (dark shading), suggesting an anomaly of kinds. The small solid dots represent a data ambiguity, presumably a typographical error (for an explanation see Appendix II).

assumes that all the genes involved are selectively (in)activated in one of the sexes, then Vargas et al. (2016) would still have to provide a selective advantage for the gradual increase in expression of the acquired characters with subsequent reproductive cycles and generations. Hence, we do not see how the genetic architecture proposed by Vargas et al. (2016) to explain Kammerer's data could have evolved.

Vargas et al. (2016) conclude that "In the light of modern scientific knowledge, we can confidently state that Kammerer's experiments do not contain any phenomenon that cannot be explained by currently known experiments and epigenetic mechanisms". We could not disagree more and we see no way in which modern science could possibly explain Kammerer's claims for the inheritance of acquired characteristics. We show, through careful examination, that there is no other than one consistent manner to explain his results and that is that they have been cooked, that is, fabricated to support his theory of evolution by acquired characters, in the midwife toad as well as in the other amphibian spe- 
cies Kammerer worked with (van Alphen \& Arntzen, 2016). We consider the reported data discrepancies to be the final nail in his coffin. To hail Paul Kammerer as an academic forbearer is a mistake the epigenetics research community might wish to avoid.

\section{Acknowledgements}

We thank Tom van Dooren (Paris) for constructive comments on an earlier version of the manuscript.

\section{Literature}

Akst J. 2017. Plants' epigenetic secrets. Scientist 31: 2835.

Alphen JJM van, Arntzen JW. 2016. Paul Kammerer and the inheritance of acquired characters. Contributions to Zoology 85: 457-470.

Arntzen JW, García-París M. 1995. Morphological and allozyme studies of midwife toads (genus Alytes), including the description of two new taxa from Spain. Contributions to Zoology 65: 5-34.

Ault KK, Johnson JE, Pinkart HC, Wagner RS. 2012. Bigger eggs in subterranean Astyanax fasciatus (Characidae, Pisces) - their significance and genetics. Zeitschrift für Zoologische Systematiek und Evolutionsforschung 29: 280-288.

Bauerfeind SS, Fischer K. 2007. Maternal body size as an evolutionary constraint on egg size in a butterfly. Evolution 61: 2374-2385.

Bentz AB, Sirman AE, Wada H, Kristen J, Navara KJ, Hood WR. 2016. Relationship between maternal environment and DNA methylation patterns of estrogen receptor alpha in wild Eastern Bluebird (Sialia sialis) nestlings: a pilot study. Ecology and Evolution 6: 4741-4752.

Bloxam QMC, Tonge SJ. 1995. Amphibians: suitable candidates for breeding-release programmes. Biodiversity and Conservation 4: 636-644.

Boulenger GA. 1912. Observation sur l'accouplement et la ponte de l'Alyte accoucheur, Alytes obstetricans. Bulletin de l'Academie Royale de Belgique, $\mathrm{Cl}$. Sci. 9-10: 570-579.

De L'Isle du Dreneuf A. 1873. Mémoire sur l'Alyte accoucheur et son mode d'áccouplement. Annales Sciences Naturelles, 5ème serie 17: 1-12.

Fischer-Sigwart H. 1885. Die Geburtshelferkröte (Alytes obstetricans). Die Natur, Halle 34: 1-3, 27-30.

Franklin A, Edwards AW, Fairbanks DJ, Hartl DL.
2008. Ending the Mendel-Fisher Controversy. University of Pittsburgh Press, Pittsburgh.

Hangartner S, Laurila S, Räsänen K. 2012. Adaptive divergence in Moor Frog (Rana arvalis) populations along an acidification gradient: Inferences from QST-FST correlations. Evolution 66: 867-881.

Hüppop K, Wilkens H. 1991. Genetic comparison of water molds from embryos of amphibians Rana cascadae, Bufo boreas and Pseudacris regilla. Diseases of Aquatic Organisms 99: 127-137.

Kammerer P. 1906. Experimentelle Veränderung der Fortpflanzungstätigkeit bei Geburtshelferkröte (Alytes obstetricans) und Laubfrosch (Hyla arborea). Archiv für Entwicklungsmechanik der Organismen 22: 48-140.

Kammerer P. 1909. Vererbung erzwungener Fortpflanzungsanpassungen. III. Mitteilung: Die Nachkommen der nicht brutpflegenden Alytes obstetricans. Archiv für Entwicklungsmechanik der Organismen 28: 447-545.

Kammerer P. 1911. Mendelsche Regeln und Vererbung erworbener Eigenschaften. Verhandlungen des naturforschenden Vereines in Brünn 49: 72-110.

Kammerer P. 1913. Vererbung erzwungener Farbveränderungen. IV. Mitteiluing: Das Farbkleid des Feuersalamanders (Salamandra maculosa Laurenti) in seiner Abhängigkeit von der Umwelt. Archiv für Entwicklungsmechanik der Organismen 36: 4-193.

Kammerer P. 1919. Vererbung erzwungener Formveränderungen. I. Mitteilung: Brunftschwiele der Alytes-Männchen aus „Wassereiern“, zugleich: Vererbung erzwungener Fortpflanzungsanpassungen, V. Mitteilung. Archiv für Entwicklungsmechanik der Organismen 45: 323-370.

Kammerer P. 1924. The Inheritance of Acquired Characteristics. Boni and Liveright, New York.

Kändler R. 1924. Die sexuelle Ausgestaltung der Vorderextremität der anuren Amphibien. Jenaische Zeitschrift für Naturwissenschaft 60 (Neue Folge 53): 175-240.

Koestler A. 1971. The Case of the Midwife Toad. Hutchinson \& Co, London.

Llusia D, Marquez R, Beltràn JF, Benitez M and Amaral J do. 2013. Calling behaviour under climate change: geographical and seasonal variation of calling temperatures in ectotherms. Global Change Biology 19: 2655-2667.

Martínez-Solano I, Gonçalves HA, Arntzen JW, García-París M. 2004. Phylogenetic relationships and biogeography of midwife toads (Discoglossi- 
dae: Alytes). Journal of Biogeography 31: 603-618.

Meng F, Braasch I, Phillips JB, Xiwen L, Titus T, Chunguan Z, Postlethwait JH. 2013. Evolution of the eye transcriptome under constant darkness in Sinocyclocheilus cavefish. Molecular Biology Evolution 30: 1527-1543.

Michaels CJ, Fahrbach M, Harding L, Bryant Z, Capon-Doyle J-S, Grant S, Gill I, Tapley B. 2016. Relating natural climate and phenology to captive husbandry in two midwife toads (Alytes obstetricans and A. cisternasii) from different climatic zones. Alytes 33: 2-11.

Miles CM, Hadfield MG, Wayne ML. 2007. Heritability for egg size in the serpulid polychaete Hydroides elegans. Marine Ecology Progress Series 340: $155-$ 162.

Nagase H, Ghosh S. 2008. Epigenetics: differential DNA methylation in mammalian somatic tissues. FEBS Journal 275: 1617-1623.

Nijs J. 1985. Enkele ervaringen met de eieren van de vroedmeesterpad, Alytes obstetricans. Lacerta 43: 82-83.

Noble GK. 1926. Kammerer's Alytes. Nature 118: 209210.

O'Quin KE, Doshi P, Lyon A, Hoenemeyer E, Yoshizawa M, Jeffery WR. 2015. Complex evolutionary and genetic patterns characterize the loss of scleral ossification in the blind cavefish Astyanax mexicanus. PLOS ONE 10: e0142208.

Sagvik J, Uller T, Ollson M. 2008a. A genetic component of resistance to fungal infection in frog embryos. Proceedings Royal Society B 275: 1393-1396.

Sagvik J, Uller T, Stenlund T, Ollson M. 2008b. Intraspecific variation in resistance of frog eggs to fungal infection. Evolutionary Ecology 22: 193-201.

Santure AW, Cauwer I de, Robinson MR, Poissant J, Sheldon BC, Slate J. 2013. Genomic dissection of variation in clutch size and egg mass in a wild great tit (Parus major) population. Molecular Ecology 22: 3949-3962.

Taschwer K. 2016. Der Fall Paul Kammerer. Das abenteuerliche Leben des umstrittensten Biologen seiner Zeit. Carl Hanser Verlag, München.

Tonge S, Bloxam, Q. 1989. Breeding the Mallorcan midwife toad Alytes muletensis in captivity. International Zoo Yearbook 28: 45-53.

Urban MC, Lewis LA, Fučíková KF, Cordone A. 2015. Population of origin and environment interact to determine oomycete infections in spotted salamander populations. Oikos 124: 274-284.

Vargas AO. 2009. Did Paul Kammerer discover epige- netic inheritance? A modern look at the controversial Midwife toad experiments. Journal of Experimental Zoology, Molecular and Developmental Evolution 312B: 667-678.

Vargas AO, Krablicher Q, Gerrero Bosagna C. 2016. An epigenetic perspective on the Midwife toad experiments of Paul Kammerer (1880-1926). Journal of Experimental Zoology, Molecular and Developmental Evolution 328: 179-192.

Voss SR, Kump DK, Walker JA, Shaffer HB, Voss GJ. 2012. Thyroid hormone responsive QTL and the evolution of paedomorphic salamanders. Heredity 109: 293-298.

Weismann A. 1887. Zur Frage nach der Vererbung erworbener Eigenschaften. Biologisches Zentralblatt 6: 33-48.

Weismann A. 1893. Das Keimplasma: eine Theorie der Vererbung. Fischer, Jena.

Wibowo A, Becker C, Marconi G, Durr J, Price J, Hagmann J, Papareddy R, Putra H, Kageyama J, Becker J, Weigel D. 2016. Hyperosmotic stress memory in Arabidopsis is mediated by distinct epigenetically labile sites in the genome and is restricted in the male germline by DNA glycosylase activity. Elife 5: e13546.

Yi G, Shen M, Yuan J, Sun C, Duan Z, Qu L, Dou T, Ma M, Lu J, Guo J, Chen S, Qu L, Wang K, Yang N. 2015. Genome-wide association study dissects genetic architecture underlying longitudinal egg weights in chickens. BMC Genomics 16: 746.

Yoshizawa M, Yamamoto Y, O'Quin KE, Jeffery WR. 2012. Evolution of an adaptive behavior and its sensory receptors promotes eye regression in blind cavefish. BMC Biology 10: 108.

Received: 28 February 2017

Revised and accepted: 7 July 2017

Published online: 18 December 2017

Editor: Alessandro Minelli 


\section{Appendix I. German texts referred to}

Kammerer 1906: 66, citing Jourdain: "Experimentell erlaubt es die Anpassungsfähigkeit der Amphibien, daß man die Larve bei den speziell differenzierten Formen jenem fischähnlichen Zustand, den man mit gutem Reeht den Ahnenzustand nennen darf, nähert oder von ihm entfernt. Die Erfahrungen Fräulein Von CHauvins zeigen dies für Salamandra atra. Experimente, die ich vor mehreren Jahren an Alytes unternahm und die Materialmangel mich unvollendet zu lassen zwang, haben mir den Beweis geliefert, daß es möglich ist, in jenem doppelten Sinne auf die Larve des genannten Anuren einzuwirken. Ich bin dazu gelangt, den Moment, in welchem die Larve das Ei verläßt und sich dem flüssigen Elemente anbequemt, beträchtlich zu beschleunigen und zu verzögern. Ich bin überzeugt, daß man mit Hilfe entsprechender Maßregeln dahin käme, jenen Batrachier in die bemerkenswerten Verhältnisse des Hylodes überzuführen oder ihn denselben doch wenigstens stark zu nähern."

Kammerer 1909: 523 "Ich zweifle aber heute nicht mehr daran, daß es im Bereiche des Möglichen liegt, Alytes eine Entwicklung, unabhängig vom Wasseraufenthalt und ohne Metamorphose, aufzuzwingen."

Kammerer 1911: 101-104 "Wir betrachten im folgenden nur je eines von diesen Pärchen, und zwar der Reihe nach jedes für sich. Zuerst dasjenige, wo das Männchen normal war. Selbstverständlich beludes es sich (und zwar noch am Abend des Isoliertages) mit den Eiern, die es seinem Weibchen abgenommen hatte und welche mit ihren 21/4 mm Durchmesser dotterärmer waren als ein auf dem Lande zu zeitigendes Alytes-Ei es sein soll. Die Schnur enthielt die für Alytes enorme Menge von 112 solcher Eier. Es zeigte sich, daß sie, die ja eigentlich fürs Wasser bestimmt waren (wo die Kopulation auch stattgefunden hatte, aber das Männchen war sogleich mit seiner Bürde herausgeklettert), tatsächlich in der Luft nicht mehr so gut fortkamen, als wünschenswert erschien, denn nur aus 49 wurden die Larven gewonnen, von letzteren nur 29 glücklich zu geschlechtstüchtigen Vollkröten großgezogen; immerhin eine Ziffer, die dem Ausfall der vom 27. September bis 2. Oktober 1907 vor sich gehenden Erstlingslaichperiode dieser Generation eine zuverlässige Basis gab. Von jenen 29 Exemplaren waren 17 weiblichen, 12 männlichen Geschlechtes. Bei der Paarung untereinander ließ es sich leicht bewerkstelligen, daß fünf Männchen je zwei Weibchen befruchteten und sich mit Dop-
pel-Laichpaketen beluden (ein Fall, der auch im Freien des öfteren beobachtet wurde); denn ein der Norm entsprechendes Beladen fand durchwegs statt, auch hatten alle Eier normale Größe (31느 - $4 \mathrm{~mm}$ Durchmesser), die Eierschnur hatte die normale Zahl von einzelnen Laichkörnern (23 - 38).

Ich dachte, wie gesagt, nicht anders, als die Instinktvariation und die daraus entspringende abweichende Zahl und Beschaffenheit der Eier sei infolge Hinzuziehung des normalen Männchens in P endgiltig erloschen. Doch isolierte ich 100 von den Jungtieren, die ich aus im ganzen 621 Eiern der ersten Mischlingsgeneration aufgezogen hatte, behufs Erzielung einer zweiten Generation von Mischlingen. Von jenen Jungen starben in den beiden dazwischen liegenden Wintern etwa die Hälfte; wenigstens erschienen aus den Winterquartieren und beteiligten sich an der Fortpflanzung, welche vom 26. April 1909 abends bis 28. April früh vor sich ging, nur 44 Mischlinge zweiter Generation, zufällig gleich viel Männchen als Weibchen. Es gab im ganzen 22 Eierschnüre mit folgenden Eimengen darin: $18,19,19,21,21,23,23,24,25,25,27,27,27,28,28,35$, 44; 88, 90, 101, 104, 105. In den ersten 15 Eierschnüren maßen die Laichkörner 4, in den folgenden zwei maßen sie $3 \frac{1}{2}$, in den letzten fünf $2^{1 / 1}-2^{1 / 2} \mathrm{~mm}$ Durchmesser. Von den 22 Männchen beluden sich 16 mit den Eierschnüren, vier ließen sie liegen, zwei versuchten zuerst, die Schnur zu tragen, um sie alsbald ebenfalls abzustreifen. Jene 17 Weibchen, welche normal (31/2 - $4 \mathrm{~mm})$ große Eier legten, taten dies anscheinend auf dem Lande; hingegen gingen die restlichen fünf, zum Zwecke der Ablage ihrer viel kleineren Eier, ins Wasser. Ob die Wahl des Laichplatzes sich wirklich völlig mit der Beschaffenheit der Eier deckt, kann ich nicht sicher aussagen, da die Verteilung jener sich verschieden verhaltenden Weibchen an die sich ebenfalls verschieden verhaltenden Männchen natürlich nicht in der Weise zustande kam, daß je ein wasserlegendes Weibchen mit einem nicht brutpflegenden Männchen und je ein landlegendes Weibchen mit einem brutpflegenden Männchen kopulierte. Vielmehr erfolgte die geschlechtliche Auslese ganz unabhängig hievon und ganz gemischt, so daß Pärchen zusamenkamen, die in ihren Neigungen zueinander paßten, aber auch Pärchen, wo das Weibchen sein widerstrebendes Männchen ins Wasser schleifte, bzw. in einem anderen Falle ihm nicht ins Wasser folgen wollte. Entscheidend bleibt zwar, wie vorhin des längeren ausgeführt, während Kopulation und Ablage der Wille des Weibchens; aber Männchen, die wider Willen ins Wasser geraten waren, hatten nichts eiligeres zu tun, als mit ihrer Last, die wegen Gallertquellung 
bereits in Verlustgefahr schwebte, das Trockene zu gewinnen, - und Männchen, die von ihren Weibchen wider Willen ans Land entführt worden waren, bekümmerten sich hier nicht weiter um den herausbeförderten Laichballen.

Wir haben nunmehr den Stammbaum des zweiten Alytes-Pärchens, desjenigen, wo das Weibchen normal, das Männchen nicht brutpflegend war, durch zwei Mischlingsgenerationen $\mathrm{zu}$ verfolgen. Am 30. August 1906 schleppte das landlegende Weibchen sein ins Wasser strebendes Männchen weit vom Bassin weg, wo schließlich die Kopulation vor sich ging. Die abgelegten Eier, vom Männchen natürlich sofort im Stiche gelassen, erwiesen sich als normal hinsichtlich Größe (4 $\mathrm{mm}$ ) und Zahl (30). Aus 28 Eiern schlüpften die normal gebildeten Larven aus, 20 erwuchsen zu zeugungsfähigen Vollkröten, 11 Männchen, 9 Weibchen. Ihre Erstlingslaichperiode fällt in den Anfang des März 1908: zwei Männchen bleiben beschäftigungslos, die übrigen neun entbinden ihre neun Weibchen von sehr kleinen $\left(2 \frac{1}{2} \mathrm{~mm}\right)$ und sehr zahlreichen (95-103) Eiern. Das Laichen findet im Wasser statt, welches beide Geschlechter einmütig aufgesucht hatten, und die Eier entwickeln sich in der wiederholt beschriebenen, Wassereiern zukommenden Art. Daraus, daß kaum welche zugrunde gehen, erkennt man, daß das Medium, in welchem sie sich entwickeln, das ihnen zuständige geworden. Ich isolierte 100 von den im ganzen gewonnenen 889 Eiern, 94 hievon ergaben Larven, 78 Vollkröten, 52 erreichten die Geschlechtsreife, die mit erster Laichperiode Ende April 1909 eintrat. Es waren 32 Männchen und 20 Weibchen. Zwölf Männchen gingen also leer aus, die übrigen kopulierten, und es gab 20 Eierschnüre mit folgenden Eizahlen darin : 100, 99, 97, 96, 96, 94, $94,93,91,91,91,88,85,77,75 ; 27,25,24,16,15$. In den ersten 15 Eierschnüren maßen die Laichkörner $2 \frac{1}{2}$, in den letzten 5 maßen sie $4 \mathrm{~mm}$ Durchmesser. Von den 20 zur Kopulation zugelassenen Männchen ließen 14 die Eierschnüre liegen, ein Männchen machte den bald wieder unterlassenen Versuch, die Schnur aufzunehmen, eines trug sie zirka eine Woche lang, um sie dann doch zu verlieren, die restlichen vier trugen das Paket bis zur Ausschlüpfreife der Larven. Hinsichtlich der Wahl des Laichplatzes ist abermals wegen gemischter Sexualauslese keine gute Uebersicht zu erlangen, aber unverkennbar zeigt sich die Tendenz, die kleinen zahlreichen Eier ins Wasser, die wenigen großen auf die Erde abzulegen.

Es waren nicht nur die eben besprochenen zwei, sondern acht Pärchen, vier mit normalen Männchen, vier mit normalen Weibchen, hinsichtlich ihrer Mischlings- nachkommenschaft zur Beobachtung gelangt. Es verbleiben also die Ergebnisse von sechs Pärchen noch zu berichten; was nicht mehr mit allen Details, sondern nur zusammenfassend zu geschehen braucht. Ein Pärchen mit normalem Männchen und zwei mit normalem Weibchen ließen nur eine erste Generation von Mischlingen aus sich hervorgehen, welche hinsichtlich weiterer Fortpflanzung versagte. Sie zeigt wie in obigen Resultaten die unbestrittene Dominanz der Merkmale väterlicherseits. Die $\mathrm{F}_{2}$ - Generation des restlichen Pärchens mit normalen Weibchen begann anfangs Mai 1909 abzulaichen, das Resultat waren auch wieder genau nur $1 / 4$ Schnüre (7) mit großen und an Zahl geringen, 3/4 Schnüre (21) mit kleinen und zahlreichen Eiern; wenige Schnüre erblickte man um die Schenkel der Männchen gewickelt, die meisten lagen lose im Wasser. Von den beiden Pärchen mit normalen Männchen liegt die zweite Mischlingsgeneration in Gestalt der zu Ende abgelegten Eier fertig vor: es sind 19 Schnüre mit den bekannten, ansehnlichen Dimensionen und geringfügigen Mengen der normalen Eier, 7 Schnüre mit kleinen zahlreichen Eiern. Und es sind 17 Männchen, welche die Schnüre (z. T. doppelte) tragen, 6 Männchen, welche sie fallen ließen.” A translation into English by Q. Krabichler is available as 'Supporting Information File 1 ' in Vargas et al. (2016).

Kammerer 1909: 462 "Es ist ja doch allgemein zu beobachten, daß Tiere, welche ihnen nicht zusagende Temperaturhöhen auszuhalten haben, im Wasser Kühlung suchen."

Kammerer 1911: 97 "Die ihnen ungewohnte Hitze veranlaßt sie nämlich, in dem ihnen stets zur Verfügung stehenden Wasserbecken Kühlung zu suchen.” 


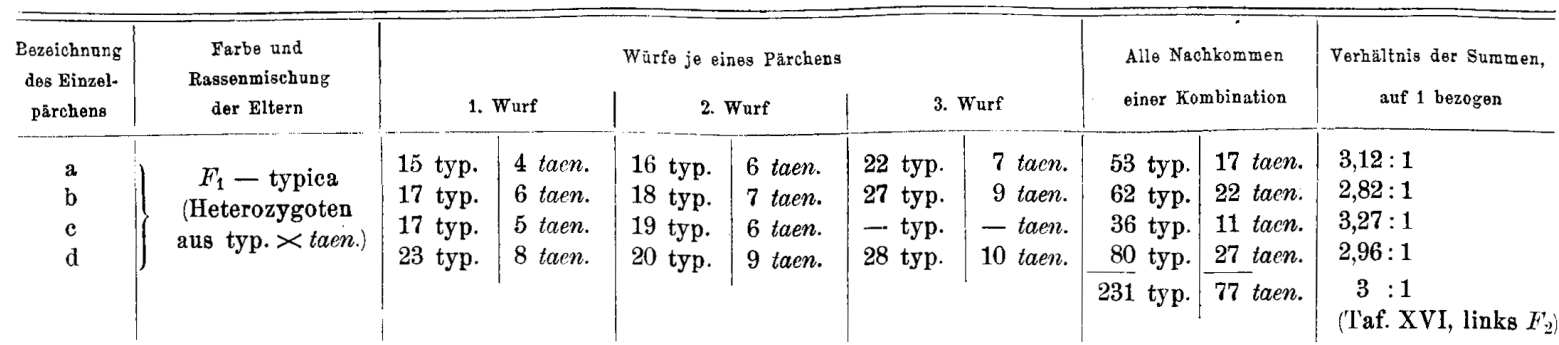

Kammerer 1913: 131 (facsimile)

Kammerer 1919: 325 "Alytes - wie die meisten, zumal nächtlichen Amphibien eher die Kühle liebend - sucht diese und Schutz vor dem Austrocknen der Haut im Wasser, sobald die Luft zu warm wird."

Kammerer 1919: 326 "Schließlich bleiben die Eier im Wasser liegen, wo die meisten zwar (in den ersten, derartigen Legeperioden) zugrunde gehen, einzelne aber sich dennoch weiterentwicklen."

Kammerer 1919: 348-349, citing Weismann "Was aber da eintritt, ist gar nichts neu Erworbenes, sondern etwas ganz altes; es ist wie Kammerer selbst sagt, 'die Rückkehr zur ursprünglichen Zeugungsart der Kröten', welche alle mit einziger Ausnahme von Alytes im Wasser laichen. Es handelt sich also hier um einen Rückschlag auf die Fortpflanzungsart weit zurückIiegender Vorfahren, die seit wohl vielen Hunderten von Generationen aufgegeben, doch nicht ganz aus dem Keimplasma als Anlage geschwunden ist und bei Einwirkung geeigneter Reize wieder in Tätigkeit tritt. Von einer sog. 'direkten Anpassung' kann nicht die Rede sein, weder bei dem Trieb ins Wasser zu gehen, noch bei den anderen Abänderungen, welche sich früher oder später dabei zeigen, z. B. dem Wiedererscheinen der 'Daumenschwielen', wie sie bei solchen ins Wasser gezwungenen Alytes-Männchen öfters auftreten, denn diese sind ein allgemeiner Besitz der im Wasser laichenden Kröten und Frösche und waren auch den Vorfahren des Alytes eigen, ja sie sind hier nicht einmal bei den in freier Natur lebenden Tieren stets geschwunden (Kammerer), ein Beweis, daß ihre Anlagen mindestens bei manchen Individuen im Keimplasma noch heute enthalten sind, bereit aktiv zu werden, wenn sie in richtiger Weise ausgelöst werden".

Kammerer, 1919: 356 “Später bessern sich ja die Resultate zusehends; im späteren Generationen der Tiere mit fertigen Instinktvariation ist die Sterblichkeit der Was- sereier kaum größer als diejenige anderer Froschlurcheier, die schon normalerweise ins Wasser abgelegt werden."

\section{Appendix II. Notes on the interpretation of Kam- merer's data}

Kammerer (1911: 101-104, reproduced in Appendix I) reports on four experiments with clearly stipulated numerical results for male as well as for female midwife toads. The results for the sexes are however not independent as illustrated by equal sample sizes. Moreover, if a female would decide to mate in water the male can only follow, etc. The results for the males are sometimes difficult to categorize, such as for example the acceptance of a batch of embryos followed by a rejection. Similarly, 'not accepting' a batch is difficult to distinguish from 'no action at all'. Conversely, the categorization of the female data is straightforward because egg-size and egg-number distributions are strongly bimodal and have corresponding class allocations. Also Kammerer's presentation is unambiguous, e.g. with numbers within classes separated by commas and classes separated by a semicolon. We therefore choose to only analyze the data for the female midwife toads.

Kammerer (1913: 131, reproduced in Appendix I) provides numerical results on the crossing between the 'typical form' of the fire salamander and the form 'taeniata'. For 'pair d' the numbers for the typical form add up to 71, instead of the reported value of 80 . The only single-character typographical error that would explain the discrepancy is that ' 20 typ.' should read '29 typ.'. In Figure 2 the printed data are reported and the correction is presented as an alternative (with no repercussions on the statistical interpretation). 